\section{Et spørsmål om balanse}

Et enkelt spørsmål om balanse kan gi en god indikasjon på risikoen for fremtidige brudd (Am J Epidemiol 2009; 169: 143-9). Nesten 25000 svenske tvillinger over 55 år svarte på en spørreundersøkelse og ble fulgt i fem år fremover.

Sannsynligheten for hoftebrudd var nesten tredoblet hos dem som rapporterte dårlig balanse i forhold til kontrollpersoner, og også økt for andre typer brudd. Sammenhengen var særlig sterk hos kvinner og hos personer over 75 år. Hos denne gruppen kan dårlig balanse være et minst like godt mål for fremtidige brudd som for eksempel beintetthetsmåling.

\section{Digital rusdagbok}

Hvilke følelser utløser trangen til å ruse seg? For å skaffe denne informasjonen er man avhengig av rapportering flere ganger om dagen. Håndholdte datamaskiner har tidligere vært brukt hos røykere, med godt resultat. Men for tunge rusmisbrukere har man antatt at det er vanskelig å gjennomføre.

Men en studie av 114 polikliniske pasienter ved en metadonklinikk i USA viser at dette lar seg gjøre (Arch Gen Psychiatry 2009; 66: 88-94). Alle unntatt 12 leverte gode data. Disse viste bl.a. at kokainmisbrukere ofte føler seg oppstemte før de tar stoffet, eller gjør det som en følge av et plutselig innfall. Heroinmisbrukere derimot følte størst trang til stoff når de var deprimerte.

\section{Hvor vellykket er \\ in vitro-fertilisering?}

Par som kommer til behandling for barnløshet ønsker å vite hvor sannsynlig det er at de får et barn. Men oftest har man bare statistikker for hvor mange fors $ø$ k med in vitrofertilisering som fører til graviditet - ikke over hvor mange kvinner som til slutt føder.

Ved en stor klinikk i Boston har man gjort en retrospektiv studie av 15000 kvinner som kom til første gangs behandling i løpet av fem år (N Engl J Med 2009; 360: 236-43).

Endepunktet var fødte barn etter opptil seks forsøk. Dette gjaldt $52 \%$ av hele utvalget. Men hvis man antok at de som ga opp hadde like stor sannsynlighet for å lykkes som de som fortsatte behandlingen, viste resultatene at behandlingen var vellykket for $72 \%$, og hele $86 \%$ av dem under 35 år. Blant kvinner over 40 år var imidlertid resultatene mye dårligere. Det betyr at in vitro-fertilisering som oftest kan «kurere» infertilitet, men at behandlingen ikke påvirker den naturlige aldersvariasjonen.

\title{
Bedre behandling av hepatitt B
}

\section{På verdensbasis er hepatitt B et stort helseproblem. Medikamenter som \\ hemmer virusreplikasjonen kan føre til at færre dør av sykdommen.}

Omkring 400 millioner mennesker i verden har kronisk hepatitt B-infeksjon. Alfainterferon var det første medikamentet som var tilgjengelig for denne pasientgruppen, og er fremdeles forstevalg i gjeldende retningslinjer. Dette til tross for at behandlingen ikke gjør pasientene virusfrie og sannsynligvis ikke hindrer utvikling av levercirrhose og hepatocellulært karsinom. De senere år har imidlertid en ny type medikamenter forandret mulighetene til å behandle hepatitt B: Nukleosid- og nukleotidanaloger hemmer viktige enzymer og dermed virusets evne til replikasjon.

I en nylig publisert studie i New England Journal of Medicine sammenliknes effekten av tenofovir, det nyeste medikamentet i denne gruppen, med det eldre adefovir (1). Endepunktet var serumnivåer av hepatitt B-virusDNA under 400 kopier per ml etter 48 ukers behandling. En klart større andel pasienter i tenofovirgruppen nådde dette endepunktet

sammenliknet med resultatene i adefovirgruppen, uavhengig av om de på forhånd var positive for hepatitt Be-antigen ( $\mathrm{HBeAg}$ ).

- Vi har tilgang på nye medikamenter med god pasienttoleranse, god effekt på suppresjon av virusreplikasjon og mindre resistensutvikling, sier overlege Eyvind J. Paulssen ved Gastromedisinsk seksjon, Universitetssykehuset Nord-Norge.

- Samtidig vet vi nå at reduksjon av virusnivået har mer å si for å hemme utviklingen av sykdommen enn fravær av antigener. Dette påvirker forståelsen av det naturlige forløpet av kronisk hepatitt B. Nyere europeiske retningslinjer vil derfor i enkelte tilfeller anbefale kontinuerlig behandling med nukleosid- eller nukleotidanaloger. Norske retningslinjer mangler, men forventes å følge de europeiske når disse kommer.

\section{Ragnhild Ørstavik}

ragnhild.orstavik@fhi.no

Tidsskriftet

\section{Litteratur}

Marcellin P. Heathcote EJ, Buti M et al. Tenofovir disoproxil fumarate versus adefovir dipivoxil for chronic hepatitis B. N Engl J Med 2008; 359: 2442-55.

\section{Langvarig behandling av hepatitt C}

\section{I en ny studie fant man ingen effekt av langvarig interferonbehandling ved kronisk hepatitt C. Men undersøkel- sen omfattet bare pasienter med alvorlig sykdom.}

Mens hepatitt B er et stort helseproblem på verdensbasis, er hepatitt $C$ langt mer utbredt i Europa og USA. De aller fleste som smittes med hepatitt C-viruset, utvikler kronisk sykdom. Halvparten av disse responderer ikke tilstrekkelig på dagens behandling - en kombinasjon av pegylert interferon- $\alpha$ (peginterferon) og perorale antivirale medikamenter (nukleotid- eller nukleosidhemmere). Denne gruppen har stor risiko for å utvikle leversvikt eller hepatocellulært karsinom og må ofte ha levertransplantasjon.

Resultater fra mindre studier tyder på at langvarig behandling med lavdose peginterferon reduserer risikoen for progredierende leversykdom hos pasienter som ikke blir virusfrie av standard behandling. Men en ny stor, randomisert studie kan ikke bekrefte dette (1). Blant over 1000 pasienter med hepatitt C-indusert leverfibrose fikk halvparten lavdose peginterferon ukentlig i 3,5 år. Sykdommen utviklet seg i negativ retning hos litt over $30 \%$ av deltakerne i begge gruppene.
Hvis man bare så på pasienter som i utgangspunktet hadde cirrhose, var også forekomsten av kliniske endepunkter den samme.

- Jeg er ikke overrasket over disse resultatene, men stiller spørsmål ved pasientutvalget. Undersøkelsen omfatter bare pasienter med langtkommen sykdom, sier avdelingsoverlege Jon Florholmen ved Gastromedisinsk avdeling, Universitetssykehuset Nord-Norge. Tidligere studier har sett på pasienter med mindre grad av leverfibrose ved behandlingsstart. Vi vil alltid starte behandling så tidlig som mulig, slik at vi unngår så langtkomne tilfeller som de som var inkludert i studien. Dersom man velger å fortsette behandling med lavdose peginterferonbehandling, vil jeg anbefale å prioritere pasienter med ingen eller lavgradig leverfibrose.

- En ny type antivirale medikamenter, proteasehemmere, ser ut til å øke behandlingseffekten. På sikt håper vi at tillegg av disse medikamentene vil hjelpe dem som ikke har effekt av dagens behandling, sier Florholmen.

\section{Ragnhild Ørstavik}

ragnhild.orstavik@fhi.no

Tidsskriftet

Litteratur

Di Bisceglie AM, Shiffman ML, Everson GT et al. Prolonged therapy of advanced chronic hepatitis $C$ with low-dose peginterferon. N Engl J Med 2008; 359: $2429-41$ 